Vol. 2 | No. 2 | 2021 | Hal. 167-174

\title{
PENGOLAHAN JAMU TRADISIONAL SEBAGAI MINUMAN PENINGKAT IMUNITAS TUBUH
}

\author{
Sama' Iradat Tito, Muhammad Ma'ruf, Arina Roikhana, Lailatul Maghfirah, Sulis \\ Setiawati, Zuhrotul Chumairoh, Nur Mufida, Durrotul Hasanah \\ Fakultas Matematika dan Ilmu Pengetahuan Alam, Universitas Islam Malang \\ *korespondensi email: sama_iradat_tito@unisma.ac.id
}

\begin{abstract}
ABSTRAK
Jamu merupakan obat tradisonal dengan bahan dasarnya berasal dari alam dengan pemberian dari warisan budaya secara turun-temurun dari generasi ke generasi. Dimasa pandemi Covid-19 ini, masyarakat disarankan untuk banyak mengonsumsi jamu dengan tujuan untuk meningkatkan imunitas tubuh selama pandemi ini. Salah satu upaya yang dapat dilakukan yakni melakukan sosialisasi kepada Ibu PKK serta perangkat Desa Srimulyo tentang pengolahan jamu tradisonal yang mempunyai potensi sebagai minuman peningkat imunitas tubuh. Metode yang digunakan yaitu metode pendekatan langsung, cerama dan praktek. Metode pendekatan yang dilakukan untuk mengetahui permasalahan yang ada di Desa Srimulyo. Metode ceramah dilakukan memberikan informasi tentang manfaat dari jamu tradisional sebagai minuman meningkatkan imunitas tubuh. Metode praktek dilakukan untuk memberikan pelatihan pengolahan jamu tradisional yang baik dan benar. Hasil yang didapat melalui kuisioner uji organoleptik didapat nilai rata-rata rasa olahan jamu tradisional 3.60, nilai rata-rata aroma olahan jamu tradisional 3.85, nilai rata-rata warna olahan jamu tradisional 3.75, dan nilai rata-rata kesukaan olahan jamu tradisional 3.70.
\end{abstract}

Kata Kunci: desa srimulyo; jamu tradisional; uji organoleptik

\section{PENDAHULUAN}

Desa Srimulyo merupakan salah satu desa yang terletak di Kecamatan Dampit Kabupaten Malang, Provinsi Jawa Timur dengan luas wilayah $20.0005 \mathrm{~km}^{2}$ dengan jumlah penduduk 14.901 jiwa pada tahun 2021. Wilayah Desa Srimulyo memiliki tanah yang sangat subur meliputi pekarangan, perkebunan, ladang, dan persawahan, sehingga sangat mungkin untuk masyarakat Desa Srimulyo meningkatkan produksi pertanian baik tanaman polowijo maupun pertanian padi bahkan pemanfaatan lahan pekarangan rumah untuk ditanami toga atau apotik hidup, dapur ataupun tanaman tahunan. Potensi Perekonomian di Desa Srimulyo adalah kopi, cengkeh, salak pondoh, tebu, empon-empon dan ketela pohon.

Berdasarkan hasil observasi yang telah kami lakukan ada beberapa hal yang menjadi permasalahan di Desa Srimulyo, diantaranya adalah minimnya pemanfaatan tanaman sekitar untuk dijadikan sebagai obat-obatan, seperti kencur, jahe, dan lain-lain. Masih banyaknya pekarangan yang kosong di Desa Srimulyo, sehingga bisa dimanfaatkan sebagai lahan penanaman obat keluarga atau apotik hidup. Dalam rangka memperdayakan dan mendorong peran aktif masyarakat dalam upaya pengembangan kesehatan tradisional perlu mengarahkan masyarakat agar dapat melakukan perawatan kesehatan secara mandiri dan benar melalui pemanfaatan tanaman obat sebagai obat tradisional berupa jamu. 
Pemanfaatan obat tradisional tersebut bertujuan sebagai upaya pemeliharaan kesehatan, pencegahan penyakit dan perawatan kesehatan termasuk pada masa kedaruratan kesehatan masyarakat atau bencana nasional Corona Virus Disease 2019 (Covid 19) (Martino et al., 2018; Saija et al., 2021). Salah satu cara untuk mengatasi masalah kesehatan dan pencegahan penularan virus Covid-19 adalah dengan melakukan atau mengkampanyekan pola hidup bersih dan sehat, maupun olahraga kepada masyarakat (Dhiani et al., 2021).

Tanaman TOGA atau yang disebut tanaman obat keluarga merupakan tanaman yang bermanfaat untuk obat yang ditanam di pekarangan rumah, kebun maupun ladang yang bertujuan untuk memenuhi kebutuhan obat sebuah keluarga. Tanaman ini ditanam dalam rangka memenuhi keperluan keluarga akan obat-obatan tradisional yang dibuat sendiri (Kementan,2015). Menurut Harjono et al. (2017) menyebutkan bahwa tanaman TOGA adalah tanaman yang didapatkan dari hasil budidaya skala rumah tangga yang mempunyai manfaat sebagai obat untuk meningkatkan kesehatan baik sebagai tindakan pencegahan, pengobatan, dan penyembuhan. Bagian dari tanaman TOGA yang dapat dimanfaatkan adalah bagian daun, kulit dari batang, buah yang dihasilkan, biji tanaman dan akar dari tanaman TOGA. Tanaman TOGA sendiri di masyarakat pada umumnya dimanfaatkan sebagai minuman kebugaran, ramuan khusus para lansia, dan untuk peningkatan gizi anak-anak.

Penggunaan tanaman sebagai alternative obat didasari dengan tingginya obat herbal yang mulai di promosikan dikalangan masyarakat. Produk-produk herbal sekarang sudah banyak mulai berkembang dan beredar di kalangan masyarakat. Menurut Susanto (2017) bahwa peningkatan penggunaan obat-obatan berbahan herbal di dunia yang semakin meningkat, hal ini berbanding terbalik dengan kesadaran masyarakat untuk mengusahakan sendiri obat-obatan yang berbahan dasar herbal. Di Indonesia, obat-obatan yang berasal dari tanaman sudah banyak sekali dikonsumsi oleh masyarakat dikarenakan harganya relatif lebih murah serta sangat mudah didapatkan di lingkungan sekitar.

Berdasarkan hasil survey yang telah dilakukan, Desa Srimulyo dapat berpotensi sebagai salah satu desa yang dapat mengembangkan suatu olahan jamu tradisional. Hal ini dikarenakan Desa Srimulyo memiliki berbagai macam bahan baku empon-empon yang sangat melimpah dan harga yang cukup murah. Jamu tradisional terdiri dari kencur, jahe, kunyit, temulawak dan bahan lainnya yang memiliki banyak manfaat seperti anti bakteri, anti fungsi dan anti virus (Dermawaty, 2015).

Pada Tanaman Kencur, kunyit dan temulawak memiliki kandungan curcumin yang dapat meningkatkan sistem imun tubuh pada manusia. Menurut Jagetia \& Aggarwal (2007) bahwa curcumin dapat memodulasi suatu pertumbuhan dan respon seluler dari berbagai macam jenis sel imun, baik pada sel T, sel B, makrofag, neutrofil, sel NK, dan sel dendritik. Selain itu, menurut Boroumand et al. (2018) menjelaskan bahwa curcumin juga dapat berperan sebagai anti inflamasi, antioksidan dan immunomuldulatory pada tubuh manusia. Sedangkan tanaman jahe juga mengandung senyawa fitokimia yang mampu meningkatkan sistem pertahanan tubuh dengan meningkatkan status antioksidan pada tubuh manusia. Dengan besarnya potensi jamu tradisional untuk peningkat imunitas tubuh maka kegiatan KSM-Tematik Kelompok 86 Universitas Islam Malang ini diharapkan dapat memberikan konstribusi dalam memutuskan rantai penyebaran virus Covid-19 melalui pengolahan jamu tradisional sebagai minuman pengingkat imunitas tubuh di era pandemi Covid-19.

\section{METODE}

Kegiatan pemberdayaan pengolahan jamu tradisional sebagai minuman peningkat imunitas tubuh kepada Ibu PKK dilaksanakan di Desa Srimulyo Kecamatan Dampit Kabupaten Malang pada tanggal 15 Agustus 2021. Kegiatan ini dilakukan oleh Dosen Pendamping Lapang dan Mahasiswa KSM-Tematik dari Kelompok 86 yang dimulai dengan 
melakukan kegiatan diskusi bersama Ketua Ibu PKK terkait rencana kegiatan pemberdayaan pengolahan jamu tradisional.

Kegiatan KSM-Tematik ini dilakukan untuk memberikan pengetahuan kepada masyarakat bahwa jamu tradisional dapat dijadikan minuman peningkat imunitas tubuh di era pandemi Covid-19. Kegiatan pemberdayaan ini meliputi survey lokasi, sosialisasi, praktek, dan melakukan uji organoleptik. Adapun tahapan yang dilakukan dalam pelaksanaan kegiatan ini sebagai berikut:

\section{Survey Lokasi}

Survey lokasi yang dilakukan di Desa Srimulyo untuk menentukan kondisi kebutuhan masyarakat, sehingga kegiatan yang dilaksanakan oleh mahasiswa KSM-Tematik kelompok 86 tepat dengan sasaran.

\section{Sosialisasi}

Sosialisasi dilakukan di desa Srimulyo yang melibatkan ibu PKK dan perangkat desa. Kegiatan ini melibatkan sebanyak 20 orang dari ibu PKK dan 5 orang dari perangkat desa.

\section{Pemberian Materi}

Pemberian materi kepada ibu PKK dilakukan oleh TIM KSM-Tematik Kelompok 86. Adapun materi yang diberikan yaitu: (1) Keunggulan dari jamu tradisional sebagai minuman peningkat imunitas tubuh di era pandemi Covid-19 dan (2) Tahapan dalam proses pengolahan jamu tradisional sebagai minuman peningkat imunitas tubuh di era pandemi Covid-19.

\section{Praktek Lapangan}

Dalam Praktek lapangan akan dilakukan proses pengolahan jamu tradisional beras kencur. Praktek ini dilakukan dari proses pengupasan dan sortasi bahan, proses pencucian bahan, proses penghalusan bahan, proses perebusan jamu, proses penyaringan jamu, proses pengemasan jamu, dan proses pelabelan jamu.

\section{Evaluasi Kegiatan}

Evaluasi Kegiatan dilakukan untuk menentukan keberhasilan pelaksanaan pemberdayaan yang telah dilaksanakan oleh ibu PKK. Evaluasi dilakukan dengan melihat kemampuan ibu PKK dalam menerima materi tentang proses pengolahan jamu.

\section{Teknik Pengumpulan Data}

Pengumpulan data yang dilakukan dengan melakukan observasi secara langsung dan memberikan kuisioner kepada ibu PKK untuk melakukan uji organoleptik pada olahan jamu tersebut.

7. Teknik Analisis Data

Analisis data yang dilakukan yakni dengan pendekatan kualitatif dan kuantitatif. Pendekatan kualitatif digunakan untuk menganalisis hasil observasi pemahaman ibu PKK selama pemberian materi pengolahan jamu sedangkan pendekatan kuantitatif dilakukan untuk menganalisis data hasil kuisioner uji organoleptik yang diberikan pada akhir kegiatan.

\section{HASIL DAN PEMBAHASAN}

Berdasarkan data hasil survey yang dilakukan 2 Agustus 2021 (Gambar 1) di Desa Srimulyo bahwa terdapat banyak tanaman TOGA yang ditanam dipekarangan rumah masyarakat. Namun, tanaman TOGA ini belum banyak dimanfaatkan oleh masyarakat Desa Srimulyo terutama kepada ibu PKK Desa Srimulyo.

Pelatihan pembuatan jamu tradisional ini bertujuan untuk memberikan cara pengolahan jamu yang baik sebagai minuman peningkat imunitas tubuh di era pandemi Covid-19 kepada ibu PKK di Desa Srimulyo. Kegiatan ini terdiri dari serangkaian kegiatan 
tentang pengolahan jamu tradisional yang diharapkan dapat memberikan dampak positif bagi kesehatan selama pandemi ini.

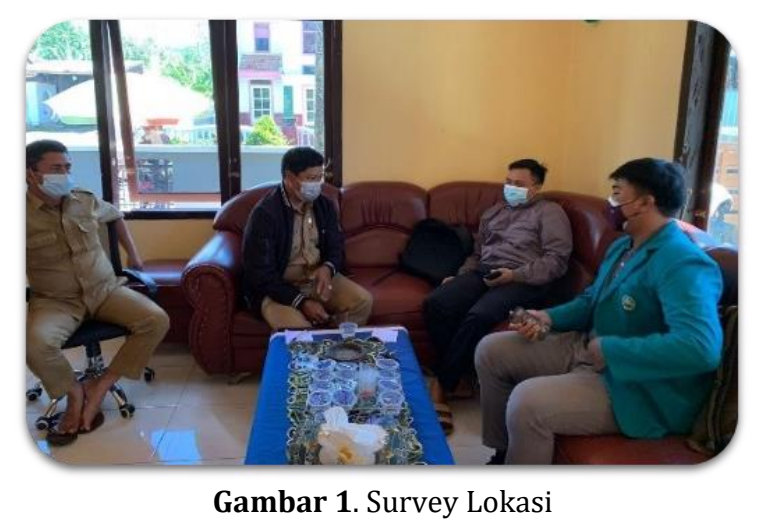

Jamu tradisional merupakan minuman yang berbahan dasar dari alam dengan pemberian dari warisan budaya secara turun-temurun dari generasi ke generasi. Jamu menurut Permenkes No. 003/MenKes/Per/I/2010 adalah ramuan yang berbahan dasar dari tumbuhan, bahan mineral, sediaan serian (generik) atau berupa campuran dari semua bahan tersebut yang diberikan secara turun temurun dan telah digunakan untuk pengobatan berdasarkan pengalaman dan diterapkan sesuai dengan norma yang terlah berlaku di masyarakat (Indariani, 2013).

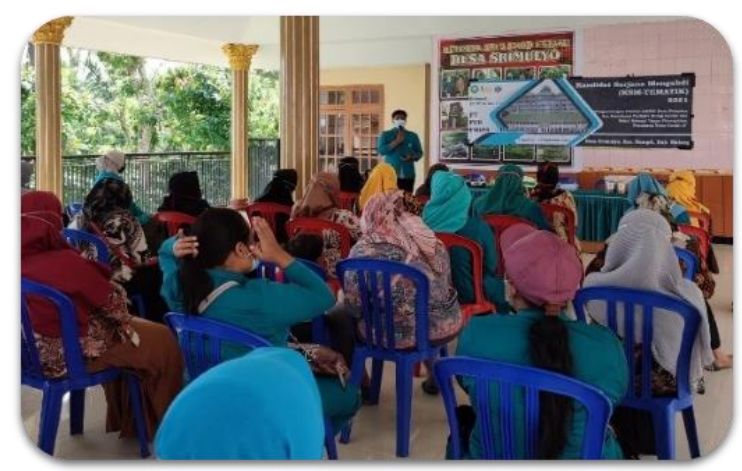

Gambar 2. Sosialisasi Pengolahan Jamu Kepada Ibu PKK serta Perangkat Desa

Berdasarkan hasil sosialisasi sekaligus pemberdayaan kepada ibu PKK pada tanggal 15 Agustus 2021 (Gambar 2), menunjukkan bahwa antusias dari ibu PKK serta perangkat desa sangat tinggi dengan dilaksanakannya kegiatan ini. Hal ini dikarenakan ibu PKK serta perangkat desa memiliki rasa kekhawatiran terhadap penularan virus Covid-19 yang dapat menular melewati kontak fisik secara langsung dan juga melewati percikan (droplet) dari penderita yang berdampak pada pneumonia dan mengakhibatkan kematian.

Pelaksanaan praktek pengolahan jamu dilakukan setelah kegiatan sosialisasi selesai (Gambar 3). Pelaksanaan kegiatan praktek ini didahului dengan memberikan selembar kertas yang berisi resep olahan jamu beras kencur kepada Ibu PKK serta perangkat desa dengan tujuan untuk mempermudah peserta dalam melakukan praktek di rumah. Selanjutnya dilakukan kegiatan pemberian materi praktek pengolahan jamu tradisional dengan tujuan untuk meningkatkan pengetahuan kepada Ibu PKK serta perangkat desa sehingga lebih aplikatif dan interaktif. Untuk mengetahui pencapaian tujuan kegiatan ini, Ibu PKK serta perangkat desa diberi kuisioner berupa uji organoleptik pada olahan jamu 
tradisional yang telah dibuat. Berdasarkan hasil kuisioner uji organoleptik yang dilakukan oleh ibu PKK serta perangkat desa, dapat dilihat pada (Tabel 1,2,3, dan 4).

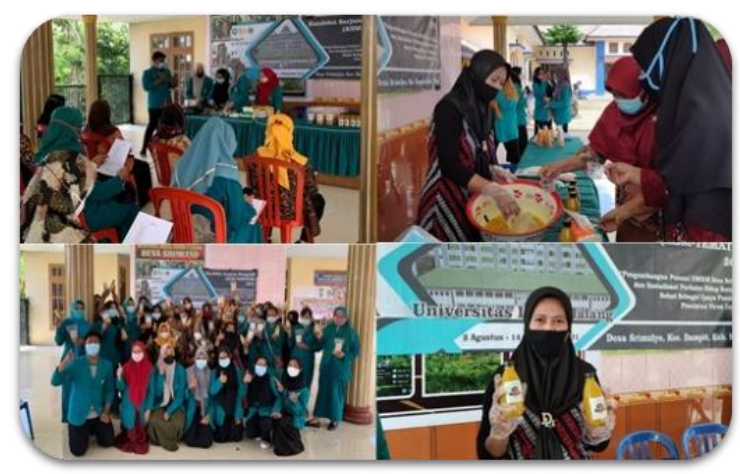

Gambar 3. Pelatihan Pembuatan Jamu Tradisional

Tabel 1. Hasil Uji Organoleptik Rasa Jamu Tradisonal Beras Kencur

\begin{tabular}{llcccc}
\hline & & \multicolumn{2}{c}{ Rasa Jamu Beras Kencur } & Valid & Cumulativ \\
& Frequency & Percent & Percent & e Percent \\
\hline \multirow{4}{*}{ Valid } & Agak Suka & 3 & 12,0 & 12,0 & 40,0 \\
& Suka & 20 & 80,0 & 80,0 & 90,0 \\
& Sangat Suka & 2 & 8,0 & 8,0 & 100,0 \\
& Total & 25 & 100,0 & 100,0 & \\
\hline \multicolumn{5}{c}{} \\
\end{tabular}

Berdasarkan uji organoleptik dari 25 orang panelis mengenai rasa pada beras kencur, terdapat 3 panelis menyatakan agak suka terhadap rasa jamu beras kencur dengan persentase (12\%), 20 panelis menyatakan suka terhadap rasa jamu beras kencur dengan persentase (80\%), dan 2 panelis menyatakan sangat suka terhadap rasa jamu beras kencur dengan persentase $(8 \%)$.

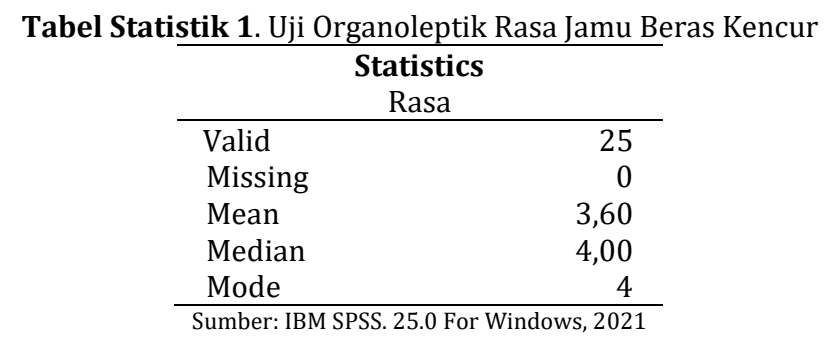

Berdasarkan tabel stastik uji organoleptik terhadap rasa jamu beras kencur, maka diperoleh rata-rata dengan nilai 3,60 yang menyatakan bahwa panelis menyukai rasa dari jamu beras kencur.

Tabel 2. Hasil Uji Organoleptik Aroma Jamu Beras Kencur

\begin{tabular}{|c|c|c|c|c|c|}
\hline \multicolumn{6}{|c|}{ Aroma Jamu Beras Kencur } \\
\hline & & Frequency & Percent & $\begin{array}{c}\text { Valid } \\
\text { Percent }\end{array}$ & $\begin{array}{l}\text { Cumulativ } \\
\text { e Percent }\end{array}$ \\
\hline \multirow[t]{4}{*}{ Valid } & Agak Suka & 3 & 12,0 & 12,0 & 30,0 \\
\hline & Suka & 15 & 60,0 & 60,0 & 90,0 \\
\hline & Sangat Suka & 7 & 28,0 & 28,0 & 100,0 \\
\hline & Total & 25 & 100,0 & 100,0 & \\
\hline
\end{tabular}


Data uji organoleptik dari 25 orang panelis mengenai aspek aroma dari jamu beras kencur, 3 panelis yang menyatakan agak suka terhadap aroma dari jamu beras kencur dengan persentase (12\%), selanjutnya sebanyak 15 panelis menyatakan suka terhadap aroma dari jamu beras kencur dengan persentase (60\%), dan terdapat 7 panelis yang sangat suka terhadap aroma dari jamu beras kencur dengan persentase (28\%).

Tabel Statistik 2. Uji Organoleptik Aroma Jamu Beras Kencur

\begin{tabular}{lr}
\multicolumn{2}{c}{$\begin{array}{c}\text { Statistics } \\
\text { Aroma }\end{array}$} \\
\hline Valid & 0 \\
Missing & 3,85 \\
Mean & 4,00 \\
Median & 4 \\
Mode & Sumber: IBM SPSS. 25.0 For Windows, 2021
\end{tabular}

Berdasarkan tabel statistik uji organoleptik terhadap aroma jamu beras kencur, maka diperoleh rata-rata dengan nilai 3,85 yang menyatakan bahwa panelis menyukai aroma dari jamu beras kencur.

Tabel 3. Hasil Uji Organoleptik Warna Jamu Beras Kencur

\begin{tabular}{llcccc}
\hline & \multicolumn{3}{c}{ Warna Jamu Beras Kencur } & & \\
& & Frequency & Percent & $\begin{array}{c}\text { Valid } \\
\text { Percent }\end{array}$ & $\begin{array}{c}\text { Cumulativ } \\
\text { e Percent }\end{array}$ \\
\hline \multirow{2}{*}{ Valid } & Agak Suka & 1 & 4,0 & 4,0 & 45,0 \\
& Suka & 19 & 76,0 & 76,0 & 80,0 \\
& Sangat Suka & 5 & 20,0 & 20,0 & 100,0 \\
& Total & 25 & 100,0 & 100,0 & \\
\hline \multicolumn{5}{c}{} & Sumber: IBM SPSS. 25.0 For Windows, 2021
\end{tabular}

Data uji organoleptik dari 25 orang panelis mengenai aspek warna dari jamu beras kencur, didapatkan 1 panelis yang menyatakan agak suka terhadap warna dari jamu beras kencur dengan persentase (4\%), selanjutnya sebanyak 19 panelis menyatakan suka terhadap warna dari jamu beras kencur dengan persentase (76\%), dan terdapat 5 panelis yang sangat suka terhadap warna dari jamu beras kencur dengan persentase (20\%).

Tabel Statistik 3. Uji Organoleptik Warna Jamu Beras Kencur

\begin{tabular}{lr}
\multicolumn{2}{c}{$\begin{array}{c}\text { Statistics } \\
\text { Warna }\end{array}$} \\
\hline Valid & 25 \\
Missing & 0 \\
Mean & 3,75 \\
Median & 4,00 \\
Mode & 4 \\
\hline Sumber: IBM SPSS. 25.0 For Windows, 2021
\end{tabular}

Berdasarkan tabel statistik uji organoleptik terhadap warna jamu beras kencur, maka diperoleh rata-rata dengan nilai 3,75 yang menyatakan bahwa panelis menyukai warna dari jamu beras kencur.

Tabel 4. Hasil Uji Organoleptik Kesukaan Jamu Beras Kencur

\begin{tabular}{llcccc}
\hline & \multicolumn{4}{c}{ Kesukaan Jamu Beras Kencur } \\
& Frequency & Percent & $\begin{array}{c}\text { Valid } \\
\text { Percent }\end{array}$ & $\begin{array}{c}\text { Cumulativ } \\
\text { e Percent }\end{array}$ \\
\hline Valid & Agak Suka & 2 & 8,0 & 8,0 & 35,0 \\
& Suka & 18 & 72,0 & 72,0 & 75,0 \\
& Sangat Suka & 5 & 20,0 & 20,0 & 100,0 \\
& Total & 25 & 100,0 & 100,0 & \\
\hline & & Sumber: IBM SPSS. 25.0 For Windows, 2021
\end{tabular}


Berdasarkan uji organoleptik dari 25 orang panelis mengenai kesukaan pada jamu beras kencur, 2 panelis menyatakan agak suka terhadap jamu beras kencur dengan persentase (8\%), 18 panelis menyatakan suka terhadap jamu beras kencur dengan persentase $(72 \%)$, dan 5 panelis menyatakan sangat suka terhadap jamu beras kencur dengan persentase (20\%).

Tabel Statistik 4. Uji Organoleptik Kesukaan Jamu Beras Kencur

\begin{tabular}{lr}
\hline & $\begin{array}{c}\text { Statistics } \\
\text { Kesukaan }\end{array}$ \\
\hline Valid & 25 \\
Missing & 0 \\
Mean & 3,70 \\
Median & 4,00 \\
Mode & 4 \\
\hline Sumber: IBM SPSS. 25.0 For Windows, 2021
\end{tabular}

Berdasarkan tabel stastik uji organoleptik kesukaan terhadap jamu beras kencur, maka diperoleh rata-rata dengan nilai 3,70 yang menyatakan bahwa panelis menyukai jamu beras kencur.

\section{KESIMPULAN}

Sosialisasi pengolahan jamu tradisional yang diselenggarakan oleh Mahasiswa Kandidat Sarjana Mengabdi (KSM-Tematik) Universitas Islam Malang diselenggarakan di Aula Balai Desa Srimulyo, Kec. Dampit, Kab. Malang. Kegiatan ini bertujuan untuk memberikan cara pengolahan jamu yang baik dan benar, menjadikan olahan jamu tradisional sebagai minuman pengingkat imunitas tubuh di era pandemi Covid-19 serta memberikan konstribusi dalam memutuskan rantai penyebaran virus Covid 19 kepada Ibu PKK serta perangkat desa. Dukungan serta respon yang sangat baik dari Ibu PKK dan perangkat desa karena program kerja ini memiliki dampak yang positif untuk masyarakat Desa Srimulyo nantinya akan menghasilkan produk jamu tradisional yang dapat dipasarkan. Sehingga harapan kedepannya masyarakat desa Srimulyo terutama ibu PKK dapat meningkatkan perekonomian ditengah wabah pandemi Covid-19 dengan berjualan produk jamu tradisional.

\section{DAFTAR RUJUKAN}

Boroumand, N., Samarghandian, S., \& Hashemy, S. I. (2018). Immunomodulatory, antiinflammatory, and antioxidant effects of curcumin. Journal of Herbmed Pharmacology, 7(4), 211-219. https://doi.org/10.15171/jhp.2018.33

Dermawaty, D. E. (2015). Potential Extract Curcuma (Curcuma xanthorrizal, Roxb) as Antibacterials. Jurnal Majority, 4(1), 5-11. https://juke.kedokteran.unila.ac.id/index.php/majority/article/view/494

Dhiani, B. A., Nurjanah, S., Putri, N. I., \& Umam, I. I. (2021). Peningkatan pengetahuan guru dan orang tua siswa taman kanak-kanak tentang penggunaan suplemen vitamin yang tepat. Jurnal Inovasi Hasil Pengabdian Masyarakat (JIPEMAS), 4(2), 161-168. https://doi.org/10.33474/jipemas.v4i2.9138

Harjono, Y., Yusmaini, H., \& Bahar, M. (2017). Penyuluhan Pemanfaatan Tanaman Obat Keluarga dan Penanaman Tanaman Obat Keluarga di Kampung Mekar Bakti 01 / 01 , Desa Mekar Bakti Kabupaten Tangerang. JPM Ruwa Jurai, 3(1), 16-22. https://doi.org/10.23960/jpm.v3i1.1933

Indariani, S. (2013). Quality of Herbal Medicine Plants and Traditional Medicine. Trop BCR IPB. $\quad$ http://biofarmaka.ipb.ac.id/brc-news/brc-article/587-quality-of-herbal- 
medicine-plants-and-traditional-medicine-2013

Jagetia, G. C., \& Aggarwal, B. B. (2007). "Spicing up" of the immune system by curcumin. Journal of Clinical Immunology, 27(1), 19-35. https://doi.org/10.1007/s10875-0069066-7

Martino, Y. A., Sulistiowati, E., \& Purnomo, Y. (2018). Model Pemberdayaan Santri Ponpes AlHidayah Batu Alang Sebagai Kader Kesehatan Berbasis Terapi Herbal. Jurnal Inovasi Hasil Pengabdian Masyarakat (JIPEMAS), 1(2), 86-93. https://doi.org/10.33474/jipemas.v1i2.1514

Saija, R., Berlianty, T., \& Radjawane, P. (2021). Pengobatan Alternatif Tradisional Untuk Mencegah Penularan Covid-19 Menurut Perspektif Hukum Kekayaan Intelektual di Kota Ambon. S A S I, 27(2), 172-186. https://doi.org/10.47268/sasi.v27i2.438

Susanto, A. (2017). Komunikasi dalam Sosialisasi Tanaman Obat Keluarga (TOGA) di Kecamatan Margadana. Parapemikir Jurnal Ilmiah Farmasi, 6(1), 111-117. https://doi.org/10.30591/pjif.v6i1.476 